\title{
Effect of steroid-free follicular fluid antiserum on reproductive endocrine profile at estrous and metestrus phases in female rats
}

\author{
J.A. Al-Sa'aidi ${ }^{1}$ and A.H. Al-Charak ${ }^{2}$ \\ Department of Physiology, Biochemistry and Pharmacology, College of Veterinary Medicine, University of Al-Qadisiyah, \\ Al-Qadisiyah, Iraq, Email: ${ }^{1}$ jbr20042002@yahoo.com or jabbar.alsaadi@qu.edu.iq, ${ }^{2}$ areejhasan69@ gmail.com
}

(Received July 14, 2019; Accepted August 1, 2019; Available online May 21, 2020)

\begin{abstract}
Inhibins are important ovarian hormones that control the action of the pituitary gonadotropins which regulate the ovarian cycle. The present experiment aims to study the role of steroid-free follicular fluid-antibodies (S-FBFF-ab) on the reproductive hormone levels at estrus and metestrus phases in cycling female rats. Follicular fluid was collected from mature ovarian follicles, centrifuged and treatment with activated charcoal. S-FBFF was isolated and used for immunization of adult male rabbits. After 5 injections, blood was withdrawn for separation of S-FBFF-ab. Eighty mature female rats were assigned into control and treatment groups (40 each). At late metestrus phase, females of the control were injected intra-peritoneally with $100 \mu \mathrm{L}$ of physiological saline, whereas treated females were injected intra-peritoneally with $100 \mu \mathrm{L}$ of S-FBFF-ab. At early estrus and early metestrus phases of each estrous cycle, serum concentrations of inhibin-B, follicle stimulating hormone (FSH), estradiol (E2), and prolactin (PRL) were estimated. The results revealed that S-FBFF-ab has inhibin immuno-neutralization effect, which caused elevation in the concentrations of serum FSH and E2, and significant decline of serum PRL and inhibin$\mathrm{B}$, at early estrus, whereas significant elevation of E2 and PRL, and significant decline of serum FSH, at early metestrus. Furthermore, the results of gene expression revealed a significant elevation of ovarian aromatase gene at both early estrus and early metestrus phases, whereas pituitary PRL gene showed significant decline at early estrus phase and significant elevation at early metestrus phase. In conclusion, passive immunization against S-FBFF could augment the reproductive efficiency through increase reproductive endocrine activity.
\end{abstract}

Keywords: inhibin-B, follicular fluid, S-FBFF antiserum, FSH hypersecretion, immunoneutralization

Available online at http://www.vetmedmosul.com, (c) 2020, College of Veterinary Medicine, University of Mosul.

This is an open access article under the CC BY 4.0 license (http://creativecommons.org/licenses/by/4.0/).

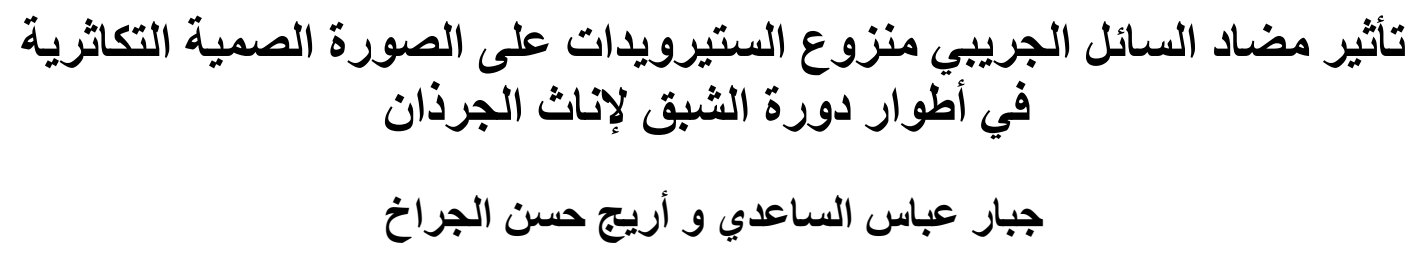

فرع الفسلجة و الكيمياء الحياتية و الأدوية، كلية الطب البيطري، جامعة القادسية، القادسية، العراق

تعد الأنهبينات من هرمونات المبيض المهمة التي تؤثر في فعل محرضات القئد التئ وتنظم الدورة المبيضية. أجريت الدراسة الحالية

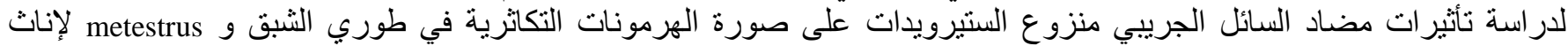

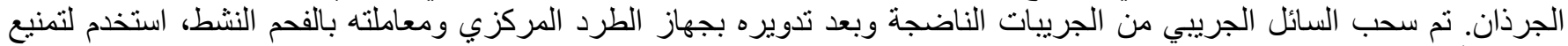

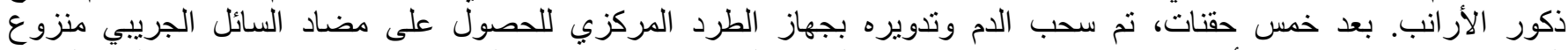

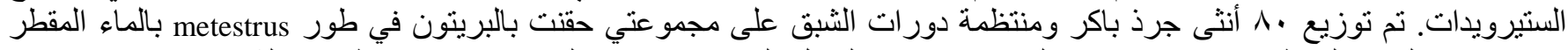

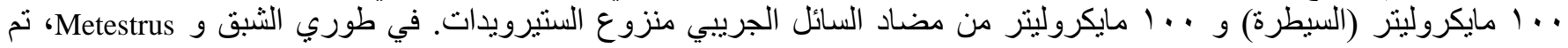




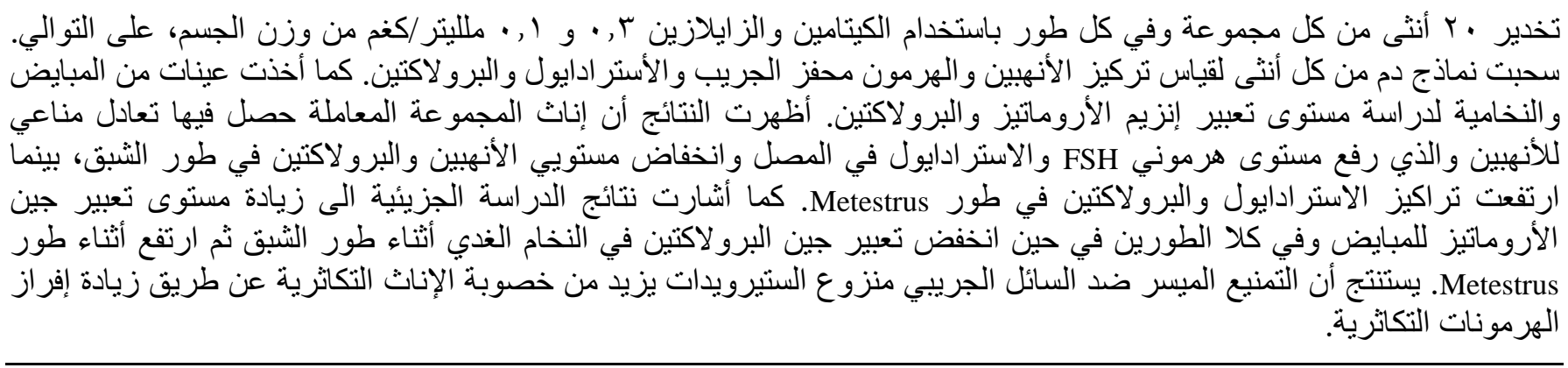

\section{Introduction}

The endocrine systems play a main role in the estrous cycle. Various hormones involved are gonadotrophins (LH and FSH), estrogen and progesterone (1). FSH promotes folliculogenesis, while LH triggers ovulation in the ovary and develops corpus luteum (2). During the development of follicles, the level of estradiol is increased.

The rise in estradiol level also stimulates the part of adenohypophysis, therefore, the combination of effects on the hypothalamus and adenohypophysis will triggers the ovulatory surge of LH (3). Researchers have other choices to be induce superovulation, other than eCG-hCG treatment, in order to solve this problem in rats and immunizing against inhibin as in other animals. Multiple discoveries have proven that immunization against inhibins stimulates superovulation in both immature and adult rats (4-10).

It is conclusive that the inhibin antiserum treating method is advantageous for both oocyte and embryo production and quality (11-13). In vitro, using a follicular culture, many factors have been revealed to increase follicular growth and development, including antrum formation, where maybe they have direct or indirect stimulatory actions on follicular antrum development as a result of follicular growth (14). Inside the ovary, privately created local estrogens synthesis act together with the Gonadotropins emitted from the anterior pituitary gland to accommodate effective follicular growth and steroid hormones production (15). In the granulosa cells, it is a very much acknowledged that FSH is the real inducer of aromatase activity. Therefore, the stimulatory impact of FSH is liable to tweaks by various mixes. A rundown of a portion of these mixes and their activities on FSH initiated aromatase expression, where the role of estradiol, androgens, and insulin is the development of factor-I (15).

Our hypothesis is inducing reproductive hormones secretion by the supplementation of the S-FBFF-ab. Therefore, the aim of the current study was to determine the role of antisera against S-FBFF on reproductive hormones profile as well as ovarian aromatase and pituitary PRL gene expression levels in two consecutive estrous cycles of cycling female rats.

\section{Materials and methods}

\section{Preparation of steroid-free bovine follicular fluid (SFBFF) antiserum}

From bovine mature follicles (equal or more than 15 $\mathrm{mm}$ in diameter), the antral fluid was collected from slaughtered cow's ovaries, centrifuged at $8000 \mathrm{rpm}$ for 15 minute, then the supernatant was treated for $90 \mathrm{~min}$. with activated charcoal $(10 \mathrm{mg} / \mathrm{ml})$, and after 60 minutes, centrifuged again at $14000 \mathrm{rpm}$ for $90 \mathrm{~min}$. at $4^{\circ} \mathrm{C}$ to discard the charcoal with attached steroids (12). The remaining S-FBFF was used to immunize 10 adult male rabbits by 5 injections of S-FBFF $(100 \mu \mathrm{L} / \mathrm{kg}$, one-week interval). One month after the fifth injection, blood was withdrawn, centrifuged to obtain S-FBFF-ab and kept at -20 ${ }^{\circ} \mathrm{C}(6)$.

\section{Experimental animals}

The present study was carried out in the agreement to the guidelines of ethics and policies of the University of AlQadisiyah. Adult cycling female Wistar rats (90 days old and $164.5 \pm 5.17 \mathrm{~g}$ weight) were housed under normal environmental conditions (12L: 12D daylight cycles and $22-24{ }^{\circ} \mathrm{C}$ temperature). The animals were fed on laboratory diet pellets (19\% protein and $3000 \mathrm{kcal}$.) and drinking water ad libitum. Only female rats with estrous cycles of 45 days have been used. Estrus phases were determined according to the method described by Mandle et al. (16).

\section{Experimental design}

Eighty female rats were randomly assigned to treatment and control groups (40 each). The females of the control group were intra-peritoneally administered, at late metestrus stage, with a single dose of normal saline (100 $\mu \mathrm{L}$ ), whereas those of treated group administered with $\mathrm{S}$ FBFF-ab $(100 \mu \mathrm{L})$. At early estrus and late metestrus phases, 20 females from each group at each phase were anesthetized with Ketamin and Xylazine $(0.3 \mathrm{ml}$ and 0.1 $\mathrm{ml} / \mathrm{kg}$ B.wt, respectively). Blood samples were withdrawn from the abdominal vein and blood sera were prepared. Serum inhibin-B, FSH, E2, and PRL concentrations were assessed using ELISA technique. The pituitary gland and ovarian tissue samples were obtained for assessment the 
expression levels of prolactin gene and aromatase gene, respectively, using qRT-PCR technique (Bioneer, Korea). These genes were normalized by using housekeeping gene (GAPDH). This technique was done according to method described by Wang and Hardy (17).

\section{Statistical Analysis}

The results of experimental groups and periods were stated as mean \pm standard deviation $(\mathrm{M} \pm \mathrm{SD})$, and were compared by one-way analysis of variance (ANOVA1) and Newman- Keuls (18). In the current study, $\mathrm{P}<0.05$ was considered as a significant level in comparison the differences between the means. All statistical analysis was carried out using the GraphPad Prism- Version 5 (SAS Institute, Inc., USA).

\section{Results}

\section{FSH}

In comparison with control, serum FSH concentration of S-FBFF-ab treated females recorded significant $(\mathrm{P}<0.05)$ increase at early estrus phase and significant $(\mathrm{P}<0.05)$ decline at late metestrus phase. In comparison between the two phases, S-FBFF-ab treated females showed significant $(\mathrm{P}<0.05)$ decline of serum FSH concentrations at metestrus phase in comparison with the early estrus phase, whereas control group female rats showed insignificant $(\mathrm{P}>0.05)$ difference between the two phases (Table 1).

\section{Estradiol}

Serum estradiol concentration of S-FBFF-ab treated female rats revealed significant $(\mathrm{P}<0.05)$ elevation in comparison with control females at both estrus and metestrus phases. In comparison between the two phases, S-FBFF-ab treated group females recorded significant $(\mathrm{P}<0.05)$ elevation at metestrus phase compared with the estrus phase, whereas control group females showed no significant $(\mathrm{P}>0.05)$ difference between the two phases (Table 1).

\section{Prolactin}

The result demonstrated in the table (1) showed significant $(\mathrm{P}<0.05)$ decline of serum prolactin concentration in S-FBFF-ab treated females, at estrus phase, and significant $(\mathrm{P}<0.05)$ elevation, at metestrus phase, compared with control females. Comparison between estrus and metestrus phases for each group, SFBFF-ab treated group female rats recorded significant $(\mathrm{P}<0.05)$ increase of prolactin concentration at metestrus in comparison with estrus phase, whereas the control group showed insignificant $(\mathrm{P}>0.05)$ difference between the two phases.

\section{Inhibin-B}

Serum Inhibin-B concentration of S-FBFF-ab treated group female rats recorded significant $(\mathrm{P}<0.05)$ decline compared with control females at the estrus phase, whereas second metestrus revealed insignificant $(\mathrm{P}>0.05)$ difference between the means of the experimental groups. In comparison between the two phases, S-FBFF-ab treated group females showed significant $(\mathrm{P}<0.05)$ decline at estrus phase compared with the metestrus phase, whereas control group females showed no significant $(\mathrm{P}>0.05)$ difference between the two phases (Table 1).

\section{Expression level of pituitary prolactin gene}

Pituitary PRL gene expression level, illustrated in table 2 , recorded significant $(\mathrm{P}<0.05)$ decline in $\mathrm{S}-\mathrm{FBFF}-\mathrm{ab}$ treated females at estrus phase, and significant $(\mathrm{P}<0.05)$ elevation at metestrus phase compared with control females. In comparison between the two phases for each group, S-FBFF-ab treated group female rats recorded significant $(\mathrm{P}<0.05)$ increase of prolactin concentration at metestrus in comparison with estrus phase, whereas the control group showed insignificant $(\mathrm{P}>0.05)$ changes between the phases.

Table 1: Serum reproductive hormone concentrations of control and S-FBFF ab treated female rats at early estrus and late metestrus phases of the estrous cycle

\begin{tabular}{lcccc}
\hline & \multicolumn{2}{c}{ At early estrus } & \multicolumn{2}{c}{ At late metestrus } \\
\cline { 2 - 5 } Hormones & Control & Treatment & Control & Treatment \\
\hline Inhibin B (ng/L) & $51.65 \pm 6.330 \mathrm{Aa}$ & $6.430 \pm 1.011 \mathrm{Bb}$ & $48.72 \pm 5.001 \mathrm{Aa}$ & $46.52 \pm 5.684 \mathrm{Aa}$ \\
FSH (IU/L) & $9,383 \pm 1.096 \mathrm{Ba}$ & $39.88 \pm 2.918 \mathrm{Aa}$ & $8.615 \pm 0.983 \mathrm{Aa}$ & $5.015 \pm 0.677 \mathrm{Bb}$ \\
E2 (ng/L) & $18.31 \pm 2.981 \mathrm{Ba}$ & $32.56 \pm 3.817 \mathrm{Ab}$ & $17.91 \pm 2.346 \mathrm{Ba}$ & $49.71 \pm 5.012 \mathrm{Aa}$ \\
PRL (ng/L) & $210.9 \pm 11.11 \mathrm{Aa}$ & $145.3 \pm 10.92 \mathrm{Ab}$ & $220.8 \pm 14.56 \mathrm{Ba}$ & $315.5 \pm 23.87 \mathrm{Aa}$ \\
\hline
\end{tabular}

C: control female rats injected with $100 \mu \mathrm{l}$ of normal saline $i p$, at late metestrus. T: treated female rats injected with $100 \mu \mathrm{l} / \mathrm{rat}$ of steroid-free bovine follicular fluid antiserum ip, at late metestrus. Data were presented as Mean $\pm \mathrm{SD}$ of 15 observations $(\mathrm{n}=15)$. Different capital letters denote significant difference $(\mathrm{P}<0.05)$ between groups for each phase. Different small letters denote significant difference $(\mathrm{P}<0.05)$ between phases for each group. 


\section{Expression level of aromatase gene in the ovary}

The ovarian aromatase gene expression level of SFBFF-ab treated group was duplicated nearly 4 and 5 times than that recorded in control female ovaries at estrus and metestrus phases, respectively. In comparison between the two phases, S-FBFF-ab treated females recorded significant $(\mathrm{P}<0.05)$ elevation at metestrus phase compared with the estrus phase, whereas control females showed insignificant $(\mathrm{P}>0.05)$ difference between the two phases (Table 2).

Table 2: Pituitary PRL and ovarian aromatase gene expression levels of control and S-FBFF ab treated female rats at early estrus and late metestrus phases of the estrous cycle

\begin{tabular}{lcccc}
\hline & \multicolumn{2}{c}{ At early estrus } & \multicolumn{2}{c}{ At late metestrus } \\
\cline { 2 - 5 } Gene & Control & Treatment & Control & Treatment \\
\hline Ovarian aromatase & $8.764 \pm 0.516 \mathrm{Ba}$ & $23.40 \pm 1.31 \mathrm{Ab}$ & $9.236 \pm 1.03 \mathrm{Ba}$ & $42.45 \pm 3.23 \mathrm{Aa}$ \\
Pituitary PRL & $10.92 \pm 0.709 \mathrm{Aa}$ & $6.443 \pm 1.01 \mathrm{Bb}$ & $10.95 \pm 1.10 \mathrm{Ba}$ & $15.57 \pm 1.96 \mathrm{Aa}$ \\
\hline
\end{tabular}

C: control female rats injected with $100 \mu \mathrm{l}$ of normal saline ip, at late metestrus. T: treated female rats injected with $100 \mu \mathrm{l} / \mathrm{rat}$ of steroid-free bovine follicular fluid antiserum $i p$, at late metestrus. Data were presented as Mean \pm SD of 15 observations $(\mathrm{n}=15)$. Different capital letters denote significant difference $(\mathrm{P}<0.05)$ between groups for each phase. Different small letters denote significant difference $(\mathrm{P}<0.05)$ between phases for each group.

\section{Discussion}

The current study illustrated that S-FBFF-ab treatment caused a significant elevation in the levels of serum FSH and estradiol, at the early estrus phase, due to passive immunization against inhibin, by preventing inhibin from its negative feedback control on FSH secretion from the pituitary gland $(9,19,20)$. This elevation could be the result of increased activin action on pituitary cells, producing gonadotropins, since stimulation the secretion of FSH is due to the functional antagonism of action between activin and inhibin, where inhibin counteracts the action of activin on the same receptors $(11,21)$. Also, betaglycan could be another way, as it has a potent effect to increase the antagonistic action of inhibin against activin-mediated FSH release from the pituitary gland (22-24). Therefore, binding both types of inhibin's (A and B) with betaglycan is fundamental for their biological activity $(25,26)$.

The results of several experiments reported that the females participated in the reproductive traits should be treated with the effectors, as the regulator of the secretion of the FSH, during the stage of early luteal phase $(6,12,13)$, where the results in the current study showed high secretion of FSH as a result of immunoneutralization of endogenous inhibin. AL-Sa'aidi et al. (10) demonstrated the high level of estradiol after 12, 24 and 36 hours of immunization against endogenous inhibin in female rats. These results are consistent with the current study. Meanwhile, the immunoneutralization against endogenous inhibin, by infusion of S-FBFF-ab caused a rapid increase of pituitary FSH secretion and delayed increase of ovarian estradiol$17 \beta$ production. This finding agreed with the result of AlSa'aidi and Thanoon (20), where the decrement of serum inhibin concentration could allow activin to perform its action on pituitary gonadotrophs to secrete more FSH because inhibins and activins are functionally antagonistic members (21).

The decreased serum reactive inhibin concentration due to passive immunization against endogenous inhibin, has been reported in the current study, which accompanied by increased serum levels of activin, FSH and estradiol have also reported by previous studies (27-30). In contrast, this decrease accompanied by a rapid elevation of serum FSH, rapid decrease of prolactin concentrations and delayed increase of serum estradiol-17 $\beta$ concentrations. These findings were also reported by Al-Sa'aidi et al. (10) and AlShwielly (31). The decrement of reactive inhibin secretion could allow activins to perform its action on pituitary gonadotrophs to secrete more FSH (21). It has been mentioned that during pregnancy, serum prolactin concentration increased significantly in anti-inhibin treated females with the progression of pregnancy (32), and reach the highest value at the third trimester of gestation (33). They also reported activation of central prolactin receptor which suppresses LH surge through GABA/GABAAR signaling. These observations could explain the previous reports on the role of prolactin in modulating hypothalamic role in regulating mammalian reproduction (34).

A review of previous research on the relationship between growth factors, such as activins and inhibins, with prolactin secretion, we found that the relationship varied according to the functional status. Prolactin increases during pregnancy, which plays a synergistic role in the presence of growth factors to increase the proliferation of the glandular tissues of the mammary gland, especially in the growth of ducts and alveoli (32); whereas the role of prolactin is different during the estrus cycle, as it has been reported, in the current study, that passive immunization against inhibin, at late metestrus, decreased the secretion of prolactin from the anterior pituitary gland. These findings mention to the similar effect of inhibin and prolactin to 
decrease the secretion of gonadotropin but in different ways, where inhibin acts directly on the gonadotrphes (7,22-24); whereas prolactin action is indirectly through hypothalamus by decreasing the secretion of hypothalamic gonadotropin releasing hormone $(9,35)$.

\section{Conclusion}

It can be concluded that administration of S-FBFF-ab support reproductive efficiency by induction of reproductive hormones secretion, which can be applicable in the farm animals.

\section{Acknowledgments}

We would like to thank the department of physiology, College of Veterinary Medicine, Al-Qadisiyah University, for providing the laboratory animals and allow to conduct the present study in its animal house.

\section{Conflict of interest}

We certify that there is no conflict of interest with any organization regarding the materials discussed in the manuscript.

\section{References}

1. Esbenshade KL, Vogel MJ, Traywick GB. Clearance rate of luteinizing hormone and follicle stimulating hormone from peripheral circulation in the pig. J Anim Sci. 1986;62(6):1649-1653. $10.2527 / \mathrm{jas} 1986.6261649 \mathrm{x}$

2. Ozell TG, Okrainetz RJ. FSH: one hormone with multipule forms, or a family of multiple hormones. In: Chedrese ED (editor). Reproductive endocrinology: A molecular approach. Saskatoon: Springer Science and Business Media; 2009. 144-160 p. 10.1007/978-0-387-881867 14

3. Zhang C, Guo L, Zhu B, Feng Y, Yu S, An N, Wang X. Effects of 3,5,30-Triiodothyronine (T3) and follicle stimulating hormone on apoptosis and proliferation of rat ovarian granulosa cells. Chin J Physiol. 2013;56(5):298-305. 10.4077/cjp.2013.bab186

4. Ishigame H, Medan MS, Wang H, Watanabe G, Kishi H, Arai KY. Induction of superovulation by immunoneutralization of endogenous inhibin in immature rats. J Reprod Dev. 2005;51:559-66. $10.1262 / \mathrm{jrd} .17020$

5. Takeo T, Nakagata N. Superovulation using the combined administration of inhibin antiserum and equine/chorionic gonadotropin increases the number of ovulated Oocyttes in C57BL/6 female mice. PLOS ONE. 2015;10(5):1-11. 10.1371/journal.pone.0128330

6. Al-Sa'aidi JA, Majhwol EM. Effect of immunization against steroidfree bovine follicular fluid on reproductive hormones profile in cycling female rats. Asian J Anim Sci. 2017;11:183-188. 10.3923/ajas.2017.183.188

7. Al-Sa'aidi JA, Majhwol EM. Pituitary FSH $\beta$ and GH and ovarian GHr, IGF-1 and IGF-2 gene expression levels in cycling female rats immunized against steroid-free bovine follicular fluid antisera. Asian J Applied Sci. 2017;5(4):770-775. https://www.ajouronline.com/index.php/AJAS/article/view/4930
8. Al-Khozai EM. Effect of steroid free bovine follicular fluid treated with anti-inhibin on ovarian folliculogenesis in mature female rats [PhD dissertation]. Al-Qadisiyah: College of Education, University of Al-Qadisiyah, Iraq; 2017. $146 \mathrm{p}$.

9. Kafaji SS, Al-Sa'aidi JA, Khudair KK. Reproductive hormones profile of Iraqi Awassi ewes immunized against synthetic inhibin- $\alpha$ subunit or steroid-free bovine follicular fluid. Iraqi $\mathrm{J}$ Vet Sci. 2017;31(2):123-128. 10.33899/ijvs.2017.145609

10. Al-Sa'aidi JA, Khudai KK, Khafaji SS. Reproductive fecundity of Iraqi Awassi ewes immunized against synthetic inhibin- $\alpha$ subunit or steroid-free bovine follicular fluid. Asian-Australisian J Anim Sci. 2018;31(8):1169-1175. 10.5713/ajas.17.0660.

11. Al-Sa'aidi JA, Baqir SM. Effect of passive immunization against inhibin-a subunit and non-steroid bovine follicular fluid (NSBFF) on mammary gland growth and development in primiparous female Wistar rats. Reprod Dom Anim. 2012;47(4):416-613. 10.1111/j.1439$\underline{0531.2012 .02119 . x}$

12. Al-Sa'aidi JA, Al-Jayashi GS. Adenohypophyseal immunohistochemical expression levels of FSH $\beta$ in cyclic virgin female rats treated with steroid free bovine follicular fluid antiserum. Int Interdicip Res J. 2016;6:18-31. 10.29079/vol17iss2art502

13. Al-Sa'aidi JA, AL-Okaily BN, AL-Shwilly HA. Uterine implantations and litter size alternation in anti- inhibin and eCG-hCG treated virgin pregnant female rats. Online Int Interdicip Res J. 2016;6(1):36-46. 10.29350/jops.2018.23.2.732

14. Irving-Rodgers HF, Hummitzsch K, Murdiyarso LS, Bonner WM, Sad Y, Ninomiya Y, Couchman JR, Sorokin LM, Rodgers RJ. Dynamics of extracellular matrix in ovarian follicles and corpora lutea of mice. Cell Tissue Res. 2010;339(3):613-24. 10.1007/s00441-009-0905-8

15. Stocco C. Aromatase expression in the ovary: Hormonal and molecular regulation. Steroids. 2008;73(5):473-487. 10.1093/med/9780199235292.003.1024.

16. Marcondes FK, Bianchi FJ, Tanno AP. Determination of the estrous cycle phases of rats: Some helpful considerations. Braz J Biol. 2002;62(4): 609-614. 10.1590/S1519-69842002000400008

17. Wang G, Hardy MP. Development of Leydig cells in the insulin- like growth factor-I (igf-I) knockout mouse: effects of igf-I replacement and gonadotropic stimulation. Biol Reprod. 2004;70:632-639. 10.1095/biolreprod.103.022590

18. Schefler WC. Statistics for biological sciences. $2^{\text {nd }}$ ed. USA: AddisonWesley Publushing; 2000. $230 \mathrm{p}$.

19. Luisi S, Florio P, Reis FM, Petraglia F. Inhibins in female and male reproductive physiology: role in gametogenesis, conception, implantation and early pregnancy. Human Reprod. 2005;11:123-135. 10.1093/humupd/dmh057

20. Al-Sa'aidi JA, ad Thanoon HB. Hypothalamic GHRH and pituitary GH gene expression levels in neonatal inibin immunoneutralized female rats. Aspire. The 5th Congress of the Asia Pacific Initiative on Reproduction; 2014, Brisbane, Australia.

21. Miyazono K, Kamiya Y, Morikawa M. Bone morphogenetic protein receptors and signal transduction. J Biochem. 2010;147:35-51. 10.1093/jb/mvp148

22. Lewis KA, Gray PC, Blount AL, MacConnel LA, Wiater E, Bilezikjian LM, Vale W. Bataglycan binds inhibin and can mediate functional antagonism of activin signaling. Nature. 2000;404:411-414. $10.1038 / 35006129$

23. Wiater E, Lewis KA, Donaldson C, Vaughan J, Bilezikjian L, Vale W. Endogenous betaglycan is essential for high-potency inhibin antagonism in gonadotropes. Mol Endocrinol. 2009;23:1033-1042. 10.1210/me.2009-0021

24. Escalona RM, Stenvers KL, Farnworth PG, Findlay JK, Ooi GT. Reducing betaglycan expression by RNA interference (RNAi) attenuates inhibin bioactivity in L $\beta \mathrm{T} 2$ gonadotropes. Mol Cell Endocrinol. 2009;307:149-156. 10.1016/j.mce.2009.03.021

25 . Groppe J, Hinck CS, Samavarchi TP. Cooperative assembly of TGF- $\beta$ superfamily signaling complexes is mediated by two disparate 
mechanisms and distinct modes of receptor binding. Mol Cell Biol. 2008;29:157-168. 10.1016/2007.11.039

26. Makanji Y, Temple PD, Walton KL, Harrison CA, Robertson DM. Inhibin $\mathrm{B}$ is a more potent suppressor of rat follicle-stimulating hormone release than inhibin $\mathrm{A}$ in vitro and in vivo. Endocrinol. 2009;150:4784-4793. 10.1210/en.2008-1783

27. Al-Sa'aidi JA, Samir MS. Effect of passive immunization against inhibin alpha subunit on ovarian growth and development in immature female Wister rats. $14^{\text {th }}$ Scientific Congress of Faculty of Medicine; 2010, Assiut, Egypt.

28. Al-Sa'aidi JA, Al-Asadi SH. Quantification of mammary Gh-r gene and $\mathrm{GH}$ expression in pregnant, delivered and lactating Wister female rats passively immunized at pregnancy against inhibin- $\alpha, \beta a$, or $\beta b$ subunits. Int J Biol Pharm Allied Sci. 2016;5(9):2070-2083. https://ijbpas.com/pdf/2016/September/1472702680MS

29. Al-Sa'aidi JA, Al-Okaily BN, Al-shwilly HA. Comparative effect of anti-inhibin and eCG-hCG supplementation on reproductive hormonal profile in virgin cycling female rats. Al-Qadisiyah J Pure Sci. 2018;23(2):1-8. 10.29350/jops.2018.23.2.732

30. Al-Sa'aidi JA, Al-Jayashi GS, Khafaji SS. Ovarian immunohistochemical expression of estradiol $17 \beta$ in cyclic female rats treated with steroid free bovine follicular fluid antiserum. AlQadisiyah J Vet Med Sci. 2018;35-42. 10.29079/vol17iss2art502
31. Al-Shwielly HA. Effect of passive immunoneutralization against endogenous inhibin on reproductive fecundity in virgin female rats and its application in Iraqi awassi ewe lambs [ $\mathrm{PhD}$ dissertation]. Baghdad: Collage of Veterinary Medicine, University of Baghdad, Iraq; 2016. 93 p.

32. Al-Sa'aidi JA, Al-Kalby JM, Al-Saeedi MJ. Effect of passive immunization against inhibin-A, -BA and -BB subunits on serum growth and differentiation hormones profile in pregnant and lactating primiparous Wister rats. Basrah J Vet Res. 2015;14(1):79-96. 10.33762/bvetr.2015.99877

33. Kandiel MM, Watanabe G, Sosa JA, Abou El-Roos ME, AbdelGhaffar AE, Li JY, Manabe N, El Azab AI, Taya K. Profiles of circulating steroids hormones, gonadtropins, immunoreactive inhibin and prolactin during pregnancy in goats and immunolocalization of inhibin subunits, steroidogenic enzymes and prolactin in the corpus luteum and placenta. J Reprod Develop. 2010;56(2):243-250. $10.1262 / \mathrm{jrd} .09-159 \mathrm{~s}$

34. Grachev P, LI XF, Goffin V, O'Byrne T. Hypothalamic prolactin regulation of luteinizing hormone secretion in the female rat. Endocrinol Soc. 2010;10:13-34. 10.1210/en.2015-1040

35. Robinson GW, Hennighausen L. Inhibins and activins regulate mammary epithelial cell differentiation through mesenchymalepithelial interactions. Development. 1997;124:2701-2708. PMID: 9226441. 